\title{
The Iberian zebro: what kind of a beast was it?
}

\author{
Carlos NORES \\ Indurot, Universidad de Oviedo, Campus de Mieres, \\ E-33600 Mieres (Spain) \\ cnores@uniovi.es
}

Arturo MORALES MUÑIZ

Laboratorio de Arquezoología, Universidad Autónoma de Madrid, E-28049, Madrid (Spain) arturo.morales@uam.es

Laura LLORENTE RODRÍGUEZ Laboratorio de Arquezoología, Universidad Autónoma de Madrid, E-28049, Madrid (Spain) Corresponding author laura.llorente@uam.es

E. Andrew BENNETT Institut Jacques Monod, UMR 7592 CNRS Université Paris Diderot, 15 rue Hélène Brion, Paris (France) bennett.andrew@ijm.univ-paris-diderot.fr

Eva-María GEIGL Institut Jacques Monod, UMR 7592 CNRS Université Paris Diderot, 15 rue Hélène Brion, Paris (France) geigl.eva-maria@ijm.univ-paris-diderot.fr

Published on 26 June 2015

Nores C., Morales Muñiz A., Llorente Rodríguez L., Bennett E. A. \& Geigl E.-M. 2015. - The lberian zebro: what kind of a beast was it? Anthropozoologica 50 (1):21-32. http://dx.doi.org/10.5252/az2015n1a2

\section{ABSTRACT}

Seven centuries before the discovery of the African zebras by the Europeans, the names zebro and zebra were given to an enigmatic equid widely reported in the Iberian Peninsula during the Middle Ages. Roughly 150 toponyms deriving from the words zebro/a have been recorded in Iberia starting from the IX ${ }^{\text {th }}$ century A.D. together with 65 Portuguese Forais and 16 Spanish Fueros (i.e. town laws) referred to these animals as onagri or zebros - Latin and Romance etimology respectively - during the XIIth and XIIIth centuries. However, the precise biological nature of the animal remains unclear

KEY WORDS

Equus hydruntinus, European wild horses, feral equids, Iberian zebro, onager. to this day. Four hypotheses have been put forward to explain the taxonomic status of the zebro: 1) Equus hydruntinus, an extinct onager; 2) the antecessor of the Sorraia horse breed; 3) a modern onager species introduced by the Muslims; and 4) a feral domestic equid, either an ass or a horse. This paper addresses the issue by reviewing the historical and nomenclatural data on the subject, while briefly covering the genetic and archaeozoological evidence that may eventually shed light on the issue. 


MOTS CLÉS
Equus hydruntinus,
chevaux sauvages
européens,
équidés marrons,
«zebro» ibérique,
onagre.

\section{RÉSUMÉ}

Le zèbre ibérique: de quel animal s’agit-il?

Sept siècles avant la découverte des zèbres africains par les Européens, les noms «zebro " et «zèbre» ont été donnés à un équidé énigmatique largement documenté dans la péninsule Ibérique au Moyen Âge. Environ 150 toponymes découlant des mots «zebro/a» ont été enregistrés dans la péninsule Ibérique à partir du IXe siècle de notre ère. De même, 65 "Forais» au Portugal et six «Fueros» en l'Espagne (comprendre: lois urbaines) mentionnent ces animaux sous le nom d' «onagres» ou de "zebros" (étymologies latine et romane, respectivement) au cours des XIIe et XIIIe siècles. Cependant, la nature biologique précise de l'animal reste incertaine, même aujourd'hui. Quatre hypothèses ont été avancées pour expliquer le statut taxonomique du «zebro»: 1) Equus hydruntinus, l'hydrontin, un onagre éteint ; 2) l'ancêtre de la race de cheval Sorraia ; 3) espèce d'onagre moderne introduite par les musulmans; et 4) équidé domestique errant, âne ou cheval. Cet article aborde la question à partir des données historiques et de nomenclature de cet animal et les confronte brièvement avec celles de la génétique et de l'archéozoologie.

\section{INTRODUCTION}

Ever since Ulisse Aldrovandi (1616) made the first zoological description of an African zebra, it was known that Pigafetta (1591), in his description of the kingdom of the Congo, specifically stated that the name "zebra" had been given to these equids by sixteenth century Portuguese traders and explorers. Ensuing zoological works referred to this matter while providing the earliest documentation of zebras in the territories of the Gulf of Guinea, East and Southern Africa (e.g., Edwards 1758; Buffon 1764; Burchell 1822; Hamilton-Smith 1841). Later, Ridgeway's influential book (Ridgeway 1905) failed to mention a key statement in the English translation of the book of Pigafetta (Pigafetta 1597) where the latter author mentioned that "zebras" were also known in Portugal and Spain at the time (lit., "But touching the rest of her carriage and qualities, she is very lusty and pleasant as a horse; and specially in going, and in running she is so light and so swift that it is admirable. In so much as in Portingale and in Castile also, it is commonly used (as it were for a proverb) 'As swift as a zebra', when they will signify an exceeding quickness"). With omissions such as this one, and as time buried most of the early works on the subject, the connection between the African and the Iberian zebras became eventually lost.

Was the proverb that Pigafetta mentioned suggesting that when the Portuguese went into Africa zebras became so well known in Portugal and Castile that they were incorporated into popular parlance? Or was it referring to a zebra-like equid that inhabited the Iberian Peninsula at that time?

The first hypothesis is rather improbable since, contrary to the case of other African animals, zebras had been scarcely reported in Europe at that time. Among the few references of African zebras previous to Pigafetta's writings, only those of Cassius Dio (IIIrd century A.D.; Cary 1927) and of Timotheus of Gaza (IVth century A.D.; Haupt 1869) mentioned an animal described as a hippotigris (lit., a "tiger horse"). Philostorgius of Cappadocia (Vth century A.D.) later described "black and white wild asses" in the Mountains of the Moon, but failed to provide a name for them (Amidon 2007), and likewise nameless were the (lit.) "striped she-asses" given as presents to the kings Alfonso X of Castile and João I of Portugal in the XIIIth and XVth centuries A.D., respectively (González Dávila 1650; Rosell 1953).

The second hypothesis, referring to the presence of a horselike animal named the zebro in the Iberian Peninsula, has been substantiated by various authors who evidenced that, as early as 882 A.D., the word cebrario (lit. the place of the zebras) was documented in Portugal (da Silveira 1948; Antunes 2006). In addition to toponyms, some 170 mentions of the word "cebra/o" and its derivatives have been thus far gathered from Portuguese and Spanish documents spanning from the IXth to the XIIth centuries A.D., and two of these include descriptions of the animal.

Though attempts have been made as early as the XVIIIth century to identify the animal named the zebro/a [e.g., Sarmiento in 1752 (Santos \& Santos 2011), and Santa Rosa de Viterbo (1799) who mentioned toponyms and medieval documents], it was not until the early $\mathrm{XX}^{\text {th }}$ century that Nunes (1925) triggered a debate that lasted for more than three decades. The consensus reached at that time claimed that the zebro was some kind of wild ass or onager that inhabited the Iberian Peninsula until the end of the XVIth century. Noteworthy among these works are those of Castro (1928) and da Silveira (1948), the latter for the synthesis it provides.

This historical debate raised no interest within researchers in the biological sciences. This was also the case with the data provided by the first Spanish biologist to address the matter. Fernández-Galiano’s papers $(1957,1958)$ were received with scepticism by scientists who distrusted evidence based on philological and historical sources. Nores and Liesau (1992) later reviewed these evidences from an archaeological standpoint and put forward the hypothesis that the Iberian zebra or zebro might have specifically been Equus hydruntinus (Regalia, 1907), an equid documented in Europe throughout the Upper Pleistocene that presumably went extinct in Iberia during the later part of the Holocene. That hypothesis was later supported by von den Driesch (2000), Arribas (2004) and Antunes (2006). 
The aims of the present paper are four-fold. We attempt: 1) to throw light, from an essentially historical perspective, on the persistence in the Iberian Peninsula after Roman times of a wild equid; 2) to confirm whether or not the name zebra and its derivatives were given in Iberia to this particular equid during the Middle Ages; 3) to confirm that the name of that equid survived by virtue of it being transposed to its African relatives, the sub-saharian zebras; and finally 4) to make an attempt to throw light on the taxonomical nature of the zebro.

\section{METHODS}

The basis of this work consisted in a search for references of the cebro through a comprehensive bibliographic review of the pertinent historical and philological works, in addition, a systematic search in recopilatory Works of historical documents and public databases of historical, literary and geographical nature. During this process a complete recopilation of medieval Portuguese Fueros (i.e. local laws) was found in the first volumen of the Portugaliae Monumenta Historica (Anonymous 1856). Likewise, crucial information has been retrieved in the literary sources, and further legal documents in the database of the "Corpus Diacrónico del Español" (CORDE database). For Spanish toponyms, use has been made of the database of the "Sistema de Información Geográfica Nacional de España” and Portuguese toponyms have been obtained from Antunes (2006).

Whenever possible, original manuscripts and texts in their source language were consulted in order to avoid an interpretation of the term zebro even though this often meant using a wealth of variants in the way of writing the name of the animal.

Data on the zebro has been allocated to three different categories: 1) Etymology; 2) Historical documentation corresponding to the Middle and Modern Ages that have provided descriptions, uses and dates; and 3) Distribution of toponyms through time and space. These three sources are closely intertwined, being often difficult to set one apart from the others but, combined, complement the information on the subject to an extent not possible when each source is used in isolation, thus have helped us to better frame the problem.

\section{RESULTS: EVIDENCES OF AN ANIMAL NAMED ZEBRO}

\section{ETYMOLOGY}

The word zebro featured several variants in Portugal and in the Spanish kingdoms. At all times, for example, it appeared both in its male and female gender variants (i.e. zebro/a) although it should be noted that its masculine version was far more abundant prior to the XIVth century, its feminine form prevailing afterwards. In the kingdom of Castile the word often combined a "c" with a "b" (i.e. cebro), whereas in Portugal it was originally written with a " $\mathrm{z}$ " and a " $\mathrm{v}$ " (i.e. zevro). In both cases, the prefixes $e$-, en- and $a$-could be incorporated into the word. In this paper we will convention- ally refer to this animal as zebro, an etymological chimera of sorts between the most frequent spelling in Castilian and its Portuguese counterpart.

Philologists concede that the etymological evolution originally turned the Latin term equus ferus (lit., "wild horse") into equiferus, and it was from this name that the words ezebro and/or enzebro derived (da Silveira 1948; Malkiel 1985; Corominas \& Pascual 1989). Such consensus finds no discrepancies as of this writing, and it is from it that philologists such as Lief (2006) and Pascual Barea (2008) conclude that the equiferus and the zebro are synonymous. On the issue of the origin of the word zebra, Malkiel (1985) lamented that several etymological treatises "outside of the hispano-portuguese corner" maintained the myth of an African origin for the term without any reliable evidence to support it.

The equivalence between the words zebro and onager, on the other hand, was established through the far more contentious way of translating the Latin onager as zebra, zebro or any of its derivatives in old romance tongue (e.g., in modern parlance, zebra/o in Portuguese and cebra/o in Spanish). Such a debatable equivalence may lie at the root of the taxonomical identity problem of the zebro.

The earliest documented case of this equivalency having occurred was noted by Fray Martin Sarmiento in 1752 and referred to the mountain pass of $\mathrm{O}$ Cebreiro, between the provinces of Lugo and León (NW Spain). Sarmiento compared a document dated to $c .1000$ A.D., where it was stated that: "pervenerunt ad Alpes montes Ezebrarii" (lit., "they reach to the mountain of the zebros") with a later text, dated c. 1250 A.D., in which the name of the animals had been translated into Latin: "ad locum qui mons dicitur Onagrorum" (lit., "at the place referred to as the mountain of the onagers"). Although the text from Sarmiento remained unpublished until recent times (Santos \& Santos 2011), his manuscript was known to various authors, many of whom apparently accepted the equivalence "zebro = onager" without further discussion (e.g., Mitchell 1859; Larousse 1876). The inverse phenomenon has been recorded on several Spanish Fueros (i.e. laws referring local rights and privileges), initially written in Latin and later translated into Spanish. Such was the case of the Fueros of Teruel (c. 1180), Cuenca (1189) and Zorita de los Canes (c. 1230) (Allen 1910; Ureña 1911; Fernández-Galiano 1957).

Following on this equivalence of probably non-equivalent names, some medieval translations of biblical texts also turned the Near Eastern "onager" into the Iberian "zebro". This was the case of the description of the onager made in the Book of Job by the Biblia Vulgata (c. 1260; Scio de San Miguel, 1814), the Bible of Arragel (1443), and of two Bibles translated into Ladino (i.e. the dialect of the Jews from Castile) (Lazar 1995) and Castilian (Lazar et al. 1994) at the beginning of the XVth century. A Latin glossary of the XIVth century did the same (Castro 1928). The clearest equivalence between the two terms is provided by the General Hestoria of Alfonso X "the Wise", a Castilian King who in the second half of the XIIIth century explicitly stated that: "onager dezimus nós que es en la nuestra lengua por asno montés o por enzebro" (lit. "Onager is what in our tongue we call a wild ass or an enzebro") (Menéndez-Pidal 1906). In many other instances, as was the case of the andalusí 
author Ibn Arabi in 1173, one simply spoke about "onagers" (in this case, near Seville) (Castro 1928).

Such an automatic equivalence between the terms onager and zebro may not only be misleading but has imposed an explanatory system of sorts upon researchers who accepted it without further questioning. Such has been the case of Antunes (2006), who argued for a late presence of the zebro in the Portuguese Algarve region by considering that toponyms of the word Alcaria derive from the Persian name given to the onager, $A l$-Khar, instead of the far more likely alternative of a derivation from the Arab word for hamlet (i.e. Al-Qariya).

Given that all of the studies on the Iberian zebro made during the first half of the $\mathrm{XX}^{\text {th }}$ century were restricted to philological analyses, it comes as no surprise that the consensus on the zebro representing an onager or else a wild ass, has remained uncontested to this day.

To return to the equiferi of Iberia mentioned by the Romans, it should be stressed that in no case did these authors refer to anything other than horses. Strabo (Jones 1923) was the first author to speak about ímாо áypíoৎ (lit., wild horses) in Hispania c. 30 B.C., and later Varro was the first one to refer to these as the equiferi of Hispania Citerore (Hooper \& Ash 1934). The last author to make use of the term equiferus in "Roman" Hispania was Isidorus of Seville in the VIIth century A.D., who explicitly set them apart from the domestic horses (Oroz \& Marcos 1994). Two centuries later, not only had the conversion of equiferus into zebro been made, but along with it went the assumption that these animals represented non-caballine equids. Such assumption lies clearly at the root of the questionable equivalence zebro $=$ onager.

\section{The Zebro in Medieval and Modern Age documents Descriptions}

We have only two descriptions of the zebro from where one can get some idea about its looks and nature. The first one is that of Brunetto Latini who around 1265 wrote that: "Zevere sono una generazione di bestie che abitano nelle parti di Spagna, cioè di Castiglia vecchia, e sono maggiori che cervi. Ed hanno li loro orecchi molto lunghi. Ed hanno una lista su per le schiene infino in sulla coda, come mulo. Ed hanno li loro piedi fessi. E la loro carne è molto buona da mangiare. E sono si correnti che l'uomo non li pote prendere in alcun modo" (Latini 1839). In other words, the zebras living in Old Castile were larger than red deer, had very long ears, featured a dorsal stripe and were very swift. Although this text stated that zebros had cleaved hooves, Aebischer (1957) believed that the term "piedi fessi" constituted, in fact, a mistranslation of the copyist of "piedi fieboli" (i.e. slender feet). This error had already been ascertained in manuscript no. 2183 of the Biblioteca Riccardiana in Florence (Goldstaub \& Wendriner 1892).

The second description appeared in a reference to the district of Chinchilla (province Albacete, SE Spain) on the 1576 topographic review of the kingdom of Spain, commanded by Philip II: "Cría en este término mucha caza de venados, jabalies y cabras monteses. En esta tierra - pues en el resto de España no se conocian - habia muchas cebras, las cuales eran a la manera de yeguas cenizosas, de color de pelo de las ratas, un poco mohinas, relinchaban como las yeguas y corrían tanto que no había caballo que las alcanzara" (lit. "This locality is rich in big game such as red deer, wild boar and wild goat. In this land - since in other parts of Spain they were unknown - there existed many zebras, rather like ash-greyish mares, with a coat colour similar to that of rats, a slightly blackish muzzle [alt., sulky nature], whinnying as mares and running so fast that no horse could ever reach them") (Ortega Rubio 1918).

The interpretation of mohino is not devoid of problems given that this polysemic term may either refer to a melancholic or a choleric temperament or else to a blackish muzzle. Within that scenario, it may be worth remarking that a text by Covarrubias (1611) described mules as featuring both a black muzzle and a malicious temperament.

Though the reference to "long ears" in the first description suggests a non-caballine equid, none of them allows one to ascertain the precise nature of the animal. In particular, nowhere are the presence of stripes on either the legs or body mentioned, as has been suggested elsewhere (see above). These stripes are named cebraduras in modern Spanish, but this word did not acquire such meaning until the XIXth century (e.g., Pagnier 1821).

Along this same line of argument, one can note the old Spanish term zebruno, describing a specific horse coat. Such term could serve as a complementary line of evidence if one could prove that the so-named coat was one resembling that of the Iberian zebros. Indeed, according to a description contemporary with that of the zebros from Chinchilla (i.e. $c$. 1540), zebruno coat "much resembles bay although it is not so clear, lying halfway between light chestnut and proper bay, and most of these (horses) have their cannons, tails and manes very dark; ... wider than in the bay coat and above the shoulders... many black hairs heading towards the neck" (Díez 1500).

\section{Interaction with humans}

Accounts of interactions between humans and zebros convey the impression that one is always confronting a wild ani$\mathrm{mal}$, and all of the references to a domestic use of the zebro in Iberia are connected with the Islamic world. In the eyes of certain authors, such use of a presumably wild equid for domestic tasks would link with a Mesopotamian tradition for the taming and use of wild onagers, and here may lie yet another reason for having considered the zebro as an onager (Clutton-Brock 1987). Could it have happened that this Near eastern tradition had reached the Arabic culture? Real or not, in the Muslim societies of Iberia the zebro was used both as a beast of burden (i.e. Fernández de Heredia $c .1385-1391$ ) and also for riding (Cervantes 1605; Wolf \& Hoffmann 1856), and at the time of the Caliphate of Córdoba, Ibn al-'Awān (XIIth A.D.) meticulously described how it was that the zebro needed to be tamed, evidencing the non-domestic status of the animal (Banquieri 1802). The only mention of a tame zebro in a non-muslim document, a 1682 dowry from Extremadura (SW Spain), dates from Modern Age (Terrón 1987).

In strong contrast with that tradition, all of the zebro references in Christian texts reveal its condition as a big-game item. Indeed, in many of the aforementioned local laws, refer- 

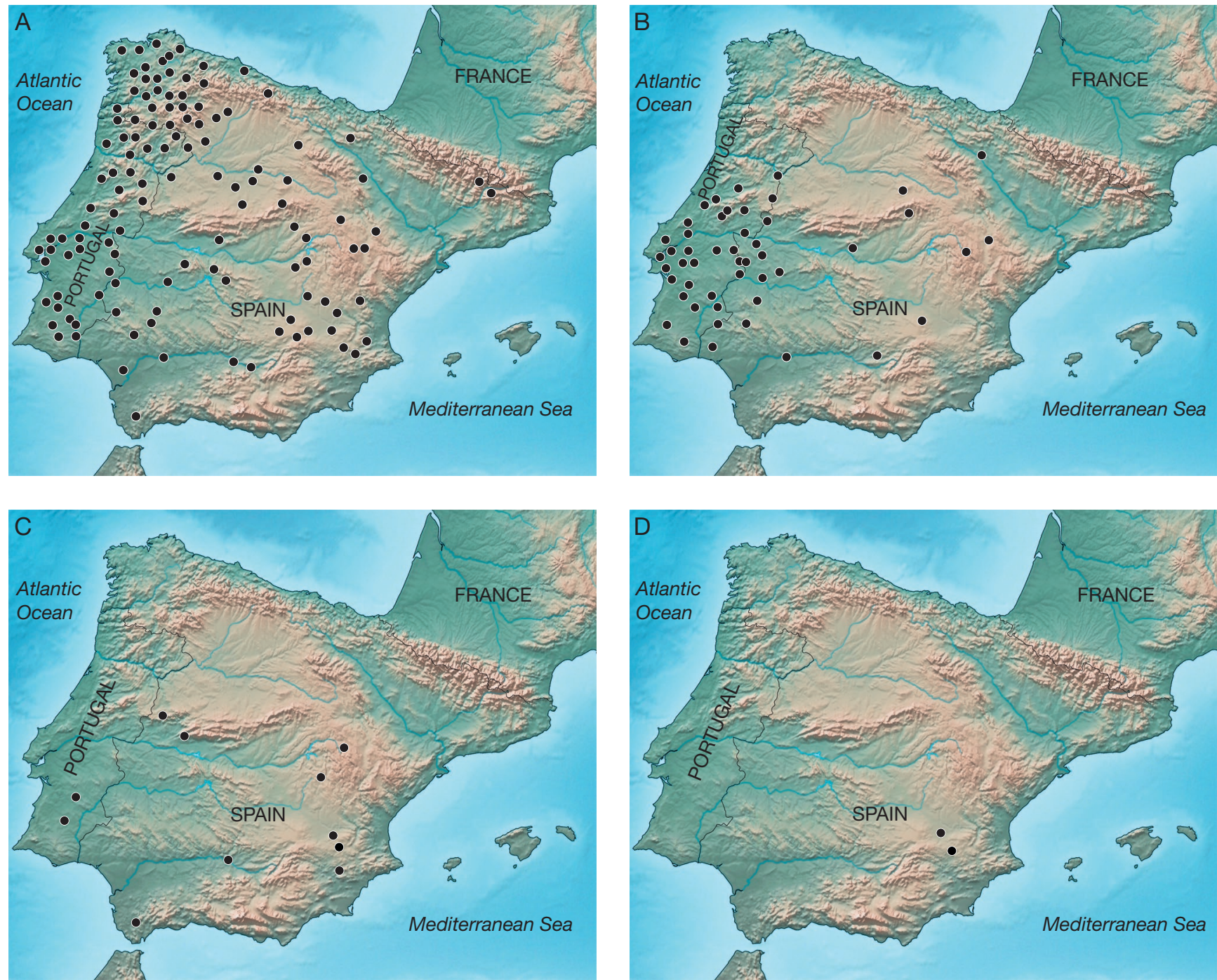

FIG. 1. - A diachronic record of the zebro based on various kinds of historical data: A. Data up to the XIIth century based mostly on toponyms; B, Data from the XIIIth century based mainly on the fueros/forais (i.e. Local laws) where the presence of the animal was mentioned; C, Data from the XIVth century based on welldated reports; $\mathbf{D}$, Last documentary records revealing its existence in the province of Albacete during the last quarter of the $\mathrm{XV} / \mathrm{l}$ century.

ences dealing with the animal involved nothing but hunting regulations. This was the case of the Boddaert, 1785 from thirteen Portuguese localities in the XIIth century, a further thirty two in the XIII't century and five in the XIVth century (Anonymous 1856). That same game status was revealed in eleven of the Fueros from the kingdom of Castile, four from the kingdom of Aragon and a further one from the kingdom of Navarre (XIIth-XIVth centuries). In many instances these laws regulated the commerce of the meat and hide from the zebro, and specified the right of possession to the hunter that first wounded it. These documents also specify that zebros were hunted with traps, arrows, and on horseback with spears (noblemen) as well, greyhounds being employed in the latter case. In the $c .1340$ A.D. hunting treatise of the Libro de la Montería by Alfonso XI of Castile, a series of localities in southeastern Spain were recorded as good hunting grounds for both "...puerco e... enzebras" (lit., wild boar and zebro) (Argote 1582).
Castro \& Onís (1916) mentioned that the hide of the zebro was not only valued for making shoes and shield covers but also in the medieval pharmacopeia. In two of his XVth century books, Latini (1839) considered the meat to be delicious and Enrique de Villena recommended it as well as the lard of the mare as a cure for laziness (Cátedra 1994). Finally, a falconry treatise from the XIIIth century considered the meat of the zebro to be a good remedy for avian tuberculosis (Fradejas 1987).

Different documents evidence that in the Christian kingdoms zebros eventually came to be considered an agricultural pest due to the damage they inflicted upon the cereal fields (Valdevira 1996). If indeed their hunting eventually turned into a systematic activity, aimed at protecting cultivated landscapes, it may explain the progressive extermination that apparently took place throughout the Middle Ages (see below).

If the decline of the Iberian zebro during the Reconquest did, in fact, run parallel with the expansion of the Christian kingdoms, one may gather that Muslims, whose religion does 
not encourage the hunting of large game, acted as a sort of "insurance" that protected the animals from extinction during the earlier part of the Middle Ages (Foltz \& Foltz 2006).

\section{Distribution and Extinction}

The chronology of toponyms associated with the word zebro or any of its derivates may provide information, albeit indirect, about the former distribution of this animal. Granting the aforementioned philological origin of the word, and also that the earliest cebrarian toponym appeared in a Portuguese document dated 882 A.D. (da Silveira 1948), it would seem reasonable to assume that toponyms derived from the word zebro must have appeared after the emergence of the romance languages, thus never prior to the VIIth century. If this was indeed the case, one can take the geographical distribution of such cebrarian toponyms as a proxy for the distribution of the equid from the Early Middle Ages onwards.

Thus far, a total of 155 zebro toponyms have been recorded in Spain and Portugal. Of these, 133 (85\%) have been located on the ground. Their geographical distribution (Fig. 1) evidences a peculiar pattern. In this way, the highest frequency of toponyms at the beginning of the sequence appeared in zones featuring an oceanic climate (i.e. Galicia and Portugal north of the Tagus river), where annual rainfall is $>1000 \mathrm{~mm}$ and the mean thermal amplitude per year often falls below $12^{\circ} \mathrm{C}$. These places correspond to some of the most forested habitats in the Iberian Peninsula to this day. From the XIVth century onwards, toponyms progressively became more frequent in areas of Spain featuring not only greater aridity (mean annual rainfall $<400 \mathrm{~mm}$ ), but also a more continental (i.e. $14^{\circ} \mathrm{C}$ of thermal amplitude per year or higher) and colder climate (i.e. > 100 days of frost per year). If toponyms were to be taken as a proxy of its distribution, one might presume that the animal progressively shifted from the more productive and climatically milder environments of the Atlantic façade of Iberia to areas featuring a harsher climate. Since human demography has been higher at all times in the former territory, and given that the zebro was hunted in the Christian lands, it is not inconceivable that such shift simply reveals a progressive reduction through time of the species' range towards those areas featuring lower human density. But one should not disconnect this trend with the Reconquest fight against the moors. Indeed, it is not until the XIIIth century that the Christian frontier reached down to the Guadalquivir River and that many areas of Andalusia and Southeastern Spain could be colonized by the Christians. Thus the "spreading" of the zebro's range towards SE Spain, when judged by the chronology of toponyms of the beast in Christian documents, may simply constitute an artifact reflecting the settling of a particular area by the Christians.

Might this information still reveal a habitat shift through time? The only written inferences to the habitat of the zebro one may deduce from vague statements referring to its endurance as a runner and from a hunting that apparently took place in open landscapes. This habitat seems consistent with

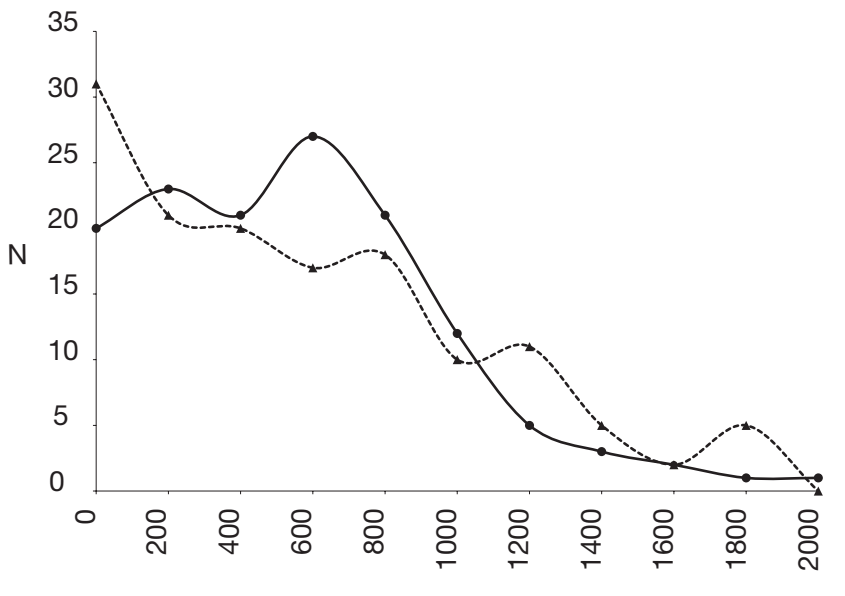

Altitudinal range $(\mathrm{m})$

FIG. 2. - Altitudinal distribution of toponyms derived from the word zebro (solid line) and expected area available at different altitudes for the Iberian Peninsula (broken line). Abbreviation: $\mathrm{N}=$ number.

an asine/onagrine equid, and, to a large extent, also with the data we have for the wild horse Equus przewalskii (Groves, 1994). But these references all date back to the Middle Ages. Paleontological data indicate that several Pleistocene horse species/populations inhabited the forests of Western Europe until fully historical times (Hainard 1962), and none of the references to wild horses made by the Romans explicitly mentioned open habitats. On the other hand, a Roman inscription on an altar to the Goddess Diana in the province of León (NW Spain), dated to 162-166 A.D., specifically stated that general Quintus Tullius Maximus of the VIIth Legio Gemina used to hunt capreas (roe deer), cervos (red deer), apros (wild boar) and equorum silvicolentum (forest horses) in that area (Pascual Barea 2008). In this case, both the name of the horse and the faunal assemblage associated with it suggest a forest environment.

Given that forests, when cleared, provide some of the most productive soils in Iberia, from these lines of evidence one could also postulate that the chronological distribution of toponyms reveals a progressive, anthropogenic, elimination of the animal in the NW Iberia once forests gave way to cultivated land.

Zebro toponyms do not exhibit any clear pattern in terms of altitude, ranging from almost sea level to localities close to $2,000 \mathrm{~m}$ above it. Significant differences $\left(\chi^{2}=15.7\right.$; d.f. $=7$; $p=0.0351$ ), however, do exist between their recorded altitudinal distribution and the expected availability of land at different altitudes in the Iberian Peninsula (Fig. 2). But the irregular clustering of toponyms at three different altitudinal ranges (i.e. 0-200 m; 600-800 $\mathrm{m}$ and 1200-1400 m) shows that this dataset is, at any rate, difficult to interpret.

The documentary data complement to a certain extent that provided by toponyms, but are equally shaky. In fact, in many Fueros derivations of the names onager or zebro were eventually taken over by the names of other animals or were simply 
TABLE 1. - Comparative survey of mentions of red deer, zebro and their synonyms (according to CORDE database, 2008).

\begin{tabular}{cccc}
\hline Century A.D. & Red deer (N) & Zebro (N) & Zebro/Red deer (\%) \\
\hline XIII & 30 & 13 & 0.433 \\
XIV & 17 & 6 & 0.353 \\
XV & 52 & 10 & 0.192 \\
XVI & 254 & 11 & 0.043 \\
XVII & 203 & 7 & 0.034 \\
XVIII & 42 & 0 & 0 \\
\hline Total & $\mathbf{5 9 8}$ & $\mathbf{4 7}$ & $\mathbf{0 . 0 7 9}$ \\
\hline
\end{tabular}

deleted. This can be taken as an indication that the zebro was non-existent at the place and time that the Fuero was granted or confirmed (Fernández-Galiano 1957). Confrontation of all these data reveals a coarse pattern evidencing a progressive restriction of documents that mention the zebro towards the Southeast of the Peninsula from the $\mathrm{X}^{\text {th }}$ to the XIIth century. At a later time only toponyms, but no mention of them in the historical sources, can be found in Galicia, the Cantabrian Mountains and the Pyrenees. By the XIIIth century, a splitting in two areas of the range where documents mention zebros, took place, followed by a marked reduction of such records during the XIVth century in both areas. The last document mentioning zebros dates to 1579 and specified that forty years earlier zebros had existed around the towns of Chinchilla and La Roda, both in the province of Albacete (SE Spain; Fig. 1) (Ortega Rubio 1918).

The zebro was never an abundant animal. This fact one can confirm by comparing references to it with those made to other species of similar characteristics, as is the case of wild ungulates. The CORDE database for example, incorporates a total of 598 records for red deer in literary works between the XIIIth and XVIIth centuries compared to a mere of 47 for the zebro. Of particular relevance is the fact that the relative frequencies of those references exhibit an inverse trend through time for both species (Table 1), a trend that in the case of the zebro roughly coincides with the presumed reduction of its distribution suggested by the documentary records.

\section{WHAT, IF ANYTHING, WAS A ZEBRO?}

Although various kinds of historical records point out that the Iberian Peninsula was apparently inhabited by a wild equid named the zebro up until the Modern Age, all of them fail to provide conclusive evidence about the taxonomic status of the beast. Indeed, documentary evidence even leaves one unsure as to whether we are confronting one or more kinds of equids. As of this writing, four hypotheses have been put forward to explain the nature of the zebro, namely:

\section{EQUUS HYDRUNTINUS}

The so-called Otranto ass or European wild ass, a hemioninelike equid present since the Middle Pleistocene in Southern and Western Europe, is the only supposedly non-caballine equid recorded in the Iberian Peninsula during the Upper Pleistocene (Arribas 2004). Despite a total dearth of osteological finds (see below) during the Holocene, the Otranto ass remains one of the favourite candidates to become the zebro despite the fragility of the evidence going for it. This evidence can be grouped into five lines of argument:

\section{Biogeography}

Paleontological data indicate that, as was the case with so many other large mammals, the Otranto ass retreated to the peninsulas of Southern Europe during the coldest pulses of the LGM (Last Glacial Maximum) stage that lasted until 14 ky BP (Willms 1989; Guérin \& Patou-Mathis 1996; Masseti 2003). Iberia had been a refugium for this species during the cold pulses of the last glacial maximum and remained in this area until the first millennium B.C., as a tree cover simulation study for Europe has recently evidenced (Crees \& Turvey 2014). The possibility that some Equus hydruntinus relict populations survived until the Holocene or even more recent times (Willms 1989) needs to be taken seriously, also given that Crees \& Turvey (2014) provide an estimated global extinction date of 580 B.C. with a confidance interval ranging from 963 B.C. - 635 A.D. As it turns out, such possibility constitutes only circumstantial evidence that, unless confirmed through alternative means, cannot be probed further at this point.

\section{Archaeozoology and palaeogenetics}

Archaeozoologists in Iberia up until the last decade have worked with the proviso in mind that, previous to the introduction of the domestic ass (Equus asinus Linnaeus, 1758) classically considered around the VIIIth century B.C., any "small" (i.e. meaning around or below one meter at the withers) equid was to be taken as evidence for the persistence of the Otranto ass. Indeed, phalanxes from small equids retrieved up until that time exhibited features similar to a hemionine rather than a caballine equid. It was this osteological evidence that led von den Driesch (2000) to postulate the persistence of E. hydruntinus up to the Iberian Bronze Age (i.e. 1.6-1.3 ky B.C.). Although this was still more than a millennium before the first documentary records of the Iberian equiferi and a couple of centuries earlier than the appearance of domestic donkeys in Iberia, the fatal blow to the argument came through ancient DNA (aDNA) analyses revealing that some of these putative $E$. hydruntinus remains were from $E$. asinus (Orlando et al. 2009), others from Equus ferus/caballus (Geigl \& Grange 2012). In other instances the identity of E. hydruntinus could be pinned down to represent hemiones, Equus hemionus Pallas, 1775 (Orlando et al. 2006; Geigl \& Grange 2012; Bennett et al. unpublished data). In particular, the measures of an extremely well preserved metacarpal originating from a layer of the cave of Artenac the floor of which was dated to about 100000 years showed that it clearly belonged to the $E$. hydruntinus group while equally clearly showing a mitochondrial DNA signature of an E. hemionus (Bennett et al. unpublished data). 


\section{Morphology and colour}

The most distinctive trait between a caballine equid and all of the remaining equids is the tail, long-haired in the horses - wild or domestic - and tufted in the hemiones, asses and zebras. Unfortunately, none of the available documents are specific about this character in the zebro. Hemiones and asses also feature longer ears than those of horses - an adaptation to hearing in a dry environment - and, as we already saw, Latini had remarked the "very long ears" of the zebros. Still, without further information, it is not prudent to settle the hemionine nature of the zebro upon this isolated remark. A stiff mane that grows higher in the Przewalski horse's head than in any of the asses or hemiones, constitutes yet another presumably diagnostic feature for a non-caballine identity of the zebro over which documentary sources remain mute. Finally, mentions of a stripe running along the dorsal midline of the body in Latini's description are non-diagnostic in the sense that several of the species of wild equids, including Przewalski's horse, the hemiones, asses and zebras, as well as several domestic breeds of both horses and asses, exhibit this feature. In Przewalski's horses, for example, a dark stripe running down the middle of the back, along with an inconspicuous shoulder stripe and distinct bars on the lower legs up to the knees, are features that appear only with the summer coat. Such coat variation, along with that documented for the horses depicted in Palaeolithic cave art (Kingdom 1979), stresses the shortcomings of arguing the taxonomic status of an equid on the sole basis of coat colouration or markings.

\section{Depictions}

As far as we know, no depictions have ever been reported in Iberian art or documents that could suggest the presence of a non-caballine equid in historical times. At this point one should remark that some Palaeolithic depictions of putative E. hydruntinus are known, in cave as well as in mobile art, in France, Spain, Italy and Switzerland (Cleyet-Merle \& Madelaine 1991). The case of "Le Hémione" from the cave of Les Trois Frères is peculiar in that the animal exhibits a combination of hemionine (i.e. long ears, short mane) and caballine (i.e. long haired tail) features (Begouën \& Breuil 1958: fig. 53). Could these have been the looks of the Otranto ass? With no contemporary depictions of the zebro for comparison, there is no evidence for or against the persistence of $E$. hydruntinus in the Iberian Holocene.

\section{Etymology}

As was previously stated, though the original derivation of the word zebro from the Latin term equiferus seems straightforward enough, the nomenclatural equivalence in Medieval Iberia of the Latin term onager and the word zebro is a far more debatable semantic trick. Although such equivalence one could take as evidence of an arguably greater morphological resemblance between the zebro and the onager than between the former animal and the domestic horse, this in no way is proof that the zebro was, in fact, a non-caballine-like equid.

On the basis of the aforementioned evidence we thus believe that the case for the zebro being the Otranto ass does not stand to any serious scrutiny, and for such reason the consensus reached 50 years ago on that identity should be squarely disregarded until new unequivocal evidence turns up.

\section{ONAGERS INTRODUCED BY THE MUSLIMS}

There does not exist a single document implying that the muslims invading Iberia after 711 A.D. took onagers or any other kind of wild equids along for the ride. Translocation of species such as the dromedary (Camelus dromedarius Linnaeus, 1758), the Algerian hedgehog (Ateleryx algirus Lereboullet, 1842) or the genet (Genetta genetta Linnaeus, 1758) have now been documented on archaeozoological grounds, yet these took place mostly during the later part of the Middle Ages (i.e. XIIth century A.D. onwards), and wild equids were apparently never part of the lot (Morales 1994; Morales et al. 1995; Morales \& Rofes 2008). Even if such translocations of equids took place, and did so at an early date, it seems improbable that onagers or Asiatic wild asses could have risen to a prominence such as to merit toponyms by the IX th century A.D. in both the North of Portugal (Oporto) and Northwestern Spain (Lugo), where Muslim influence had already ended. Even though the hypothesis must remain open, we believe that the case as of this writing is feeble to the point of not meriting further consideration.

\section{THE SORRAIA HORSE}

This Portuguese breed of the domestic horse, whose candidacy to it being the zebro has gained momentum recently, has done so on account of two lines of evidence.

\section{Genetics}

A decade ago, a DNA study claimed that the Sorraia could be a direct descendant of the European wild horse related with Przewalski horse (Jansen et al. 2002). Comparison of the ancient mitochondrial DNA sequences obtained from European E. hydruntinus remains with the corresponding DNA sequences from Sorraia breeds in Genbank, however, does not reveal a close genetic relationship and argues against the latter ones being the enigmatic Otranto ass (Bennett et al. unpublished data).

\section{Distribution and morphology}

Some of the anatomical features attributed to the zebro, such as its ashy grey coat, the dark stripe running down the middle of its back, and the fact that they whinnied coincide with features from this breed, and have led authors like d'Andrade (1926) and more recently Cordeiro (1997) to consider the Sorraia either a descendant of the zebro or the zebro itself. But these features, along with the fact that the distribution of this breed around Lisbon coincides with one of the presumed core territories of the medieval zebros, constitute weak, purely circumstantial, and non-specific "evidences" (see previous coat color discussion).

In case of having been translocated by the Spanish conquistadores, the sharing of distinct morphological, chromatic and genetic resemblances between the SW USA Sorraia mustangs and the Portuguese Sorraias (Roda 2009), could be taken to 
indicate that the breed could have had a wider distribution in the Iberian Peninsula during the XVIth century than the one it presently exhibits.

Incidentally, the case of the presumably wild zebro becoming the undoubtedly domestic Sorraia constitutes the latest instance of a long tradition dating back to Antonius (1936) that postulated the Iberian Peninsula as an independent center for the domestication of the horse (Uerpmann 1990). Although, as in the case of the E. hydruntinus and onagers introduced by the Muslims, future data - in this case genetic evidence - may prove the hypothesis to be true, at this point one cannot but judge the evidence going for it extremely feeble.

\section{A FERAL EQUID?}

The reported wild and indomitable nature of the zebro, the fact that it was hunted and that it eventually turned into an agricultural pest, while stressing that one would not be here confronting a conventional domestic animal, does not mean that the alternative must necessary to be a wild animal for a third possibility always exists, namely, that of a feral (i.e. a domesticate gone wild). Feral animals are a recurrent, however poorly documented, theme ever since the Neolithic and Iberia seems to have been no exception to the rule, best exemplified by feral cats and dogs (Zeder 2012).

Feral animals have been a tough subject for researchers of past faunas, not least because of the headaches of recognizing them in the first place. When the setting loose of such animals is documentarily recorded (e.g., American mustangs) ferals pose no major problem, but when the process goes unrecorded, such recognition becomes far more problematic to establish. This has been the case of the dingo and the mouflon whose looks, clearly distinct from those of any domestic breed of dogs or sheep, bear strong resemblances to their agriotypes (Zeder 2012). Forster (in Buffon 1782) and Pallas (1794) believed that the enigmatic Tarpan from Ukraine and southern Russia was a feral horse. Could this have been also the case of the zebro?

The evidence going for feralisation, a radically new way to look at the issue, is still far from compelling, but such hypothesis reconciles to a certain extent several independent lines of evidence. To start, archaeozoology reveals that wild horses had already become extinct in Iberia by Roman times (Uerpmann 1990). Also, conceding that the term equiferus must have signaled any horse different from a domestic animal, and that the zebros did not obviously look domestic to people, it is not inconceivable that what Strabo and Varro termed equiferi might not have been wild animals in the proper cultural and biological sense of the word. Still, accounts of the beasts being hunted and difficult to tame stress the fact that the zebro was by no means a conventional domesticate. Add to it a total dearth of data on the presence of hemionine equids in Iberia during the Holocene, and the case for a feral beast starts gaining ground.

But what kind of a feral equid could it have been? Was it a horse, an ass, or could it have been both? Although there are no historical mentions to feral equids during classical and medieval times, the possibility exists that certain Portuguese toponyms referring to "Asna brava" (i.e. wild she-ass) and the references to the "asno de montaña" (i.e. mountain ass) in the General Estoria of King Alfonso X, and the Livro del Cavallero et del Escudero of the infante D. Juan Manuel (1330), refer not to wild but to feral asses instead (Menéndez Pidal 1906). Based on an incorrect assignal of an E. hydruntinus remain that turned out to be Equus asinus (Orlando et al. 2009) and the discovery of African presumably domestic ass in the Iberian Chalcolithic probably "domestic donkeys (E. asinus) turned feral (...) during several stages of their record, related to epidemic diseases which led to the abandonment of field" (Cardoso et al. 2013: 4484). Obviously, this issue should rank second on the research agenda, although it is difficult to accept that if the major demographic and economic crises that hit the Iberian Peninsula started around the mid-XIVth century A.D. (Valdeón 1980), the word "zebro" had been documented as toponym five centuries earlier, and two centuries further back in time to refer to the animal.

Horses should, in principle, have been far more prone to becoming feral than asses. The reasons for this are varied. They may have to do with the ethology (i.e. horses tend to be far more restless/uneasy than donkeys) as well as with stockbreeding practices, donkeys being mostly bred within the realm of the farm rather than in the open. But purely stochastic reasons might also explain a higher probability of horses becoming feral. Indeed, by virtue of them being often bred in far larger numbers than asses, horses would have always stood higher chances of some individuals escaping human control. Additional deterministic reasons (e.g., horses being more often abandoned after a battle, etc.) are far more difficult to test. But time could have played a role as well. In this way, data indicate that domestic horses may have already been present in Iberia by Chalcolithic times (i.e. third millennium B.C.), whereas donkeys appeared on the scene more than two thousand years later (see above). For all these reasons, we believe that the case for the zebro being a feral horse appears stronger than that of a feral donkey, although, at this point, and given that donkeys were introduced in Iberia eight centuries prior to the Roman invasion, one would do well not to dismiss the latter possibility either. The reports of the zebro being a gregarious animal appear more coincident with the behavior and social structure of the horse than with that of the more solitary ass.

As for the issue of size, one should not be misled by prejudice when confronting documentary or archaeozoological data. Domestic horses in modern time tend to be larger than domestic donkeys, and the presumably wild Przewalski's horse is also slightly larger than any of the wild asses. But size, as color, is a highly labile trait in equids, both wild and domestic. Among the latter, some donkey breeds presumably going back to late medieval times, such as the Poitou or the Ampurdán, are as large as most of the improved horse breeds, except for the largest ones (i.e. draught horses). At the same time, a group of horse "breeds", collectively known as ponies, tend to be smaller than the Przewalski's horse. Of these, the northern mountains of Iberia (Cantabria and the Pyrenees) still feature some presumably ancient breeds, such 
as the Asturcón, the Jaca Navarra or the Basque Pottoka, incorporating animals below one meter at the withers (i.e. similar in size to some of the smallest donkey breeds). All of these breeds tend to be short-legged whereas the zebro was described as a long-legged beast but here again the ecomorphological plasticity of equids should not be forgotten: all of these northern Iberian ponies live in mountains, where stout legs are more appropriate than slender legs. If the zebro was not a mountain animal, and instead inhabited landscapes were prolonged running was feasible, one should not be surprised that its legs were far more slender than those of the mountain ponies. As with coat colour and size, the clues to solve the conundrum of the taxonomical nature of the zebro may not lie here at all.

\section{CONCLUSIONS}

In case it was a feral, the Iberian zebro would not be the only case of a feral equid being mistaken for a wild animal. St. Venance (Venantius Fortunatus) had made references as early as the VIth century A.D. of "onagers" being hunted around the town of Metz, between the Vosgues and the Ardennes mountains (i.e. NW France; Nisard 1887). These "onagers" were much later argued to be hemiones by Thevenin (1943) and wild horses by Hainard (1962) and Himly (1980), paralleling a debate that bears many coincidences with the one addressed in this paper.

Ecomorphological plasticity lies at the base of the extremely confused taxonomy of European horses of the Pleistocene and the case of the zebro may be just another case in point (Eisemann \& Guérin 1984; Bignon 2004). Western Europe was indeed inhabited by hemiones but this was previous to the onset of the Holocene (Guerin \& Patou-Mathis 1996). References to "onagers" in historical documents may thus only constitute instances of labeling with an improper Latin term equids that educated people were positive did not only represent conventional domesticates but also animals whose looks coincided with what the Latin works referred to as onagers. Only in Iberia do we have evidence that another Latin term - equiferi - had previously derived into a local voice - e-zebro, and all of its derivatives - that later not only fuelled a profound nomenclatural confusion, but also lend its name to the African zebras.

In order to definitively clear the case, it appears that paleogenetics may prove to be the only reliable tool. As said, equid plasticity at the ecomorphological level and also in terms of colour and coat designs is, just as size, far too labile a trait to provide diagnostic clues on the nature of the zebro. One should also keep in mind that all references to presumably wild European horses, from Cape St. Vincent in Portugal to the Urals in Russia, between the XIIIth and XIX ${ }^{\text {th }}$ centuries A.D. systematically coincide on three features, namely: a smaller size than that of the domestic horse; an ashy-grey color; and a black stripe on the back. Could this be a mere coincidence?
Documentary sources have often been equally ambiguous. Paleogenetics, on the other hand, has thus far managed to dismiss the presence of hemionine equids in the Holocene of Iberia and to place some of the putative E. hydruntinus remains squarely within the taxonomic realm of the donkeys and horses. But at this point one still cannot prove that all of the presumable $E$. hydruntinus remains reported from the European and Iberian Holocene represent true horses, hemiones or donkeys. One thus hopes that a systematic program of ancient DNA analyses will not only help clear the issue and evidence which species were involved in this secular problem of "taxonomic disinformation" that the Iberian zebro has come to exemplify. Even if it eventually succeeds in clearing the true nature of the zebro, paleogenetics would only provide an appropriate "background" against which all of the remaining data should be confronted and reconciled. This is the challenge we now face. As things presently stand, one should get ready for surprises!

\section{REFERENCES}

Aebischer P. 1957. — Le zebro «âne sauvage» de la Péninsule Ibérique et Brunetto Latini. Boletim de Filologia 16 (3/4): 165-175. AldROVANDi U. 1616. - Quadrupedibus solipedibus. Volumen integrum. Apud Victorium Renatium, Bononiae, 527 p.

Allen G. H. 1910. - Forum Conche; the Latin Text of the Municipal Charter and Laws of the City of Cuenca, Spain. Part IL. The University of Cincinnati Press, Cincinnati, $134 \mathrm{p}$.

ANDRADE R. D' 1926. - Apontamentos para um estudo sobre a origem e domesticação do cavallo na Peninsula Hiberica. Aproximaçóes. Centro Tipografico Colonial, Lisboa: $30 \mathrm{p}$.

Amidon P. L. 2007. - Philostorgius. Church History. Society for Biblical Literature, Atlanta, $284 \mathrm{p}$.

AnONYMous 1856. - Portugaliae Monumenta Historica a saeculo octavo post Christum usque ad quintumdecimum. Leges et consuetudines Volumen I. Typis Academicis, Olisipone [Lisboa] (Kraus Reprint Ltd., Nendeln, Liechstenstein, 1967), 656 p.

ANTONIUS O. 1936. - Zur Abstammung des Hauspferdes. Zeitschrifft für Tierzüchtung und Züchtungsbiologie 34: 359-398.

ANTUnEs M. T. 2006. - The Zebro (Equidae) and its extinction in Portugal, with an Appendix on the noun zebro and the modern "zebra", in MASHKOUR M. (ed.), Equids in Time and Space. Papers in Honour of Véra Eisenmann. Oxbow Books, Oxford: 210-235.

ARGOTE G. 1582. - Libro de La Montería que mando escrevir el muy alto y muy poderoso Rey Don Alfonso de Castilla y de León. Andrea Pescioni, Sevilla.

ARIAS B. 1614. - Discursos predicables en las festividades de los santos que con mayor solemnidad celebra la Iglesia. Juan Crisóstomo Garriz, Valencia.

ARribas O. 2004. - Fauna y paisaje de los Pirineos en la Era Glaciar. Lynx Edicions, Bellaterra, Barcelona, 540 p.

BANQUIERI J. A. 1802. - Libro de agricultura, Su autor el doctor excelente Abu Zacaría Iahia Abem Mohamed ben Ahmea Ebn Awan, Sevillano. Tomo segundo. Imprenta Real, Madrid, 756 p.

BegouëN H. \& Breuil H. 1958. - Les cavernes du Volp, Trois frères, Duc d'Audoubert à Montesquieu-Avantès, Ariège. Travaux de l'Institut de Paléontologie Humaine, Paris, 124 p.

BigNON O. 2004. - Habitat préférentiel et connectivité des chevaux tardiglaciaires d'Europe occidentale (Equus caballus arcelini, Guadelli, 1991). Archaeofauna 14: 267-284.

BUFFON COMTE DE 1764. - Histoire naturelle, générale et particulière, avec la description du Cabinet du Roi. Tome XII. Imprimerie Royale, Paris, 452 p. 
BUFFON COMTE DE 1782. - Histoire naturelle, générale et particulière, Supplément, Tome sixième. Imprimerie Royale, Paris, 431 p.

BuRCHELL W. J. 1822. - Travels in the Interior of Southern Africa, Vol. I. Longman, Hurst, Rees, Orme and Brown, London, $582 \mathrm{p}$.

Cardoso J. L., Vilstrud J. T., EisenManN V. \& OrLando L. 2013. - First evidence of Equus asinus L. in the Chalcolithic disputes the Phoenicians as the first to introduce donkeys into the Iberian Peninsula. Journal of Archaeological Science 40: 4483-4490.

CARY E .1927. - Cassius Dio. Roman History, Vol. IX. Loeb Classical Library, Harvard University Press, 489 p.

CASTRO A. \& Onís F. 1916. - Fueros leoneses de Zamora, Salamanca, Ledesma y Alba de Tormes. Junta para la Ampliación de Estudios e Investigaciones Científicas-Centro de Estudios Históricos, Madrid, $339 \mathrm{p}$.

CASTRO A. 1928. - La palabra "Zebro". Boletín de Filología Española 15: 173-179.

CÁTEDRA P. M. 1994. - Obras completas de Enrique de Villena. 1 : Los doce trabajos de Hércules; Tratado de la lepra; Arte cisoria; Tratado de consolación; Exposición del salmo 'Quoniam videbo'; Tratado de fascinación o de aojamiento; Epistola a Suero de Quiñones; Arte de trovar; Exposición del soneto de Pet. Turner Libros, Madrid, $575 \mathrm{p}$.

Cervantes M. DE 1605. - El ingenioso Hidalgo don Quixote de la Mancha. Juan de la Cuesta, Madrid, 727 p.

Cleyet-Merle J. J. \& Madelaine S. 1991. - La pendeloque magdalénienne gravée d'un "Equus hydruntinus» de la grotte du Putois II, commune de Montmaurin (Haute-Garonne). Paléo 3: 119-129.

ClutTON-BROCK J. 1987. - A Natural History of Domesticated Mammals. Cambridge University Press, British Museum of Natural History, London, Cambridge, 207 p.

CordeIro A. R. 1997. - Lusitano horse: Son of the wind. Ediçôes Inapa, Lisboa, $321 \mathrm{p}$.

COROMINAS I. \& PASCUAL J. 1989. - Diccionario Crítico Etimológico Castellano e Hispánico. Vol. 2. CE-F. Ed. Gredos, Madrid, 986 p.

Covarrubias S. 1611. - Tesoro de la Lengua Castellana o Española. Luis Sánchez, Madrid, 691 p.

Crees J. J. \& Turvey S. T. 2014. - Holocene extinction dynamics of Equus hydruntinus, a late surviving European megafaunal mammal. Quaternary Science Reviews 91: 16-29.

Díez M. 1500. - Libro de Albeytería. Juan de Burgos, Valladolid.

DRIESCH A. VON DEN 2000. - Revision zumVorkommen des Equus (Asinus) hydruntinus (Regalia, 1907) im Chalkolithikum der Iberischen Halbinsel. Archaeofauna 2: 35-38.

EDWARDS G. 1758. - Gleanings of Natural History, exhibiting quadrupeds, birds, insects, plants etc. Royal College of Physicians, London, $108 \mathrm{p}$.

EISENMANN V. \& GUERIN C. 1984. - Morphologie fonctionelle et environnement chez les Périssodactyles. Geobios 8: 69-74.

Fernández de Heredia J. c. 1385-1391. - Grant Crónica de Espanya (Tercera partida). Ms. 10134 Biblioteca Nacional de Madrid.

FERNÁNDEZ-GALIANO D. 1957. - El enzebro o asno salvaje en el Teruel medieval y consideraciones sobre su extinción. Teruel 17-18: 127-141.

FERNÁNDEZ-GALIANO D. 1958. - Sobre la extinción del enzebro o asno salvaje en los Montes Universales. Publicaciones del Instituto de Biología Aplicada 27: 165-170.

FolTz R. C. \& FolTz R. 2006. - Animals in Islamic tradition and Muslim Cultures. Oneworld, Oxford, 192 p.

Fradejas J. M. 1987. - Libro de los animales que cazan (Kitab al-yawarih). Ed. Casariego, Madrid, 308 p.

GeigL E.-M. \& Grange T. 2012. — Eurasian wild asses in time and space: Morphological versus genetic diversity. Annals of Anatomy 194, 88-102. doi: 10.1016/j.aanat.2011.06.002

GOLDSTAUB M. \& WendRINER R. 1892. — Ein tosco-venezianischer Bestiarius. M. Niemeyer, Halle, 526 p.

GONZÁlEZ-DÁvILA G. 1650. - Teatro eclesiástico de las Iglesias metropolitanas y catedrales de los Reynos de las dos Castillas. Vidas de sus arzobispos y obispos, y cosas memorables de sus sedes. Tomo tercero. Diego Díaz de la Carrera, Madrid, $457 \mathrm{p}$.

Groves C. P. 1994. - Morphology, Habitat, and Taxonomy, in Boyd L. \& Houpt K. A. (eds), Przewalski's Horse. The History and Biology of an Endangered Species. State University of New York Press, Albany: 39-60.

Guérin C. \& Patou-Mathis M. 1996. — Les Grands Mammiferes Plio-Pléistocènes d'Europe. Masson, Paris, $291 \mathrm{p}$.

Hainard R. 1962. — Mammiferes sauvages d'Europe. II: Pinnipèdes, Ongulés, Rongeurs, Cétacés. Delachaux et Niestlé, Neuchâtel, 354 p.

Hamilton-SMiTH C. 1841. - Mammalia. Horses. The Naturalist's Library. Vol. XX. Chatto and Windus, London, $352 \mathrm{p}$.

HAUPT M. 1869. - Excerpta ex Timothei Gazaei libris de animalibus. Hermes 3 (1): 1-30.

Himly F. J. 1980. — Éléments d'une histoire des mammifères d'Alsace: les mammifères disparus ou rares, in KEMPF C. \& Baumgrant G. (eds), Mammiferes d'Alsace. Les Guides Gesta, Strasbourg: 14-42.

Hooper W. D. \& AsH H. D. 1934. - De re Rustica, M. Terenti Varronis. Loeb Classical Library, Harvard University Press, London.

InSTITUTO GEOGRÁfICO NACIONAL. Database resource consulted June 11th, 2008 from www2.ign.es/iberpix/visoriberpix/visorign.html

Jansen T., Forster P., Levine M. A., Oelke H., Hurles M., Renfrew C., Weber J. \& OleK K. 2002. - Mitochondrial DNA and the origin of the domestic horse. Proceedings of the National Academy of Science 99 (16): 10905-10910.

JONES H. L. 1923. - The Geography of Strabo. Loeb Classical Library. Vol. II. Book III. Harvard University Press, Cambridge, Massachusetts, $496 \mathrm{p}$.

JUAN MANUEl INFANTE DON 1330. - Libro del cavallero y del escudero. Retrieved January 1st, 2012 from http://www.biblioteca-antologica.org/

Kingdom J. 1979. - East African Mammals: An Atlas of Evolution in Africa, Volume 3, Part B. The University of Chicago Press, Chicago.

Larousse P. 1876. - Zébre. Grand Dictionnaire Universel du XIXe Siècle. Tome quinzième. Administration du Grand Dictionnaire Universel, Paris, 1464, 1465.

LATINI B. 1839.- Il tesoro di Brunetto Latini vagarizzato da Bono Gianboni. Vol. I: Tipi del Gondoliere, Venezia, 431 p.

LAZAR M. 1995. - Biblia Ladinada: Escorial I.J.3. Hispanic Seminary of Medieval Studies, Madison, $364 \mathrm{p}$.

LAZAR M. 1996. - Biblia de Ferrara. Fundación José Antonio de Castro, Madrid, 1303 p.

Lazar M., Pueyo F. J. \& Enrique-arias A. 1994. - Biblia Romanceada, Real Academia de la Historia, MS 87 15th Century. Hispanic Seminary of Medieval Studies, Madison, 354 p.

Lief E. A. 2006. - Syincope in Spanish and Portuguese: The Diachrony of Hispano-Romance phonotactics. Partial Fulfilment of the Requirements for the Degree of Doctor of Philosophy, Faculty of the Graduate School, Cornell University, New York, 351 p.

MalKiel Y. 1985. — Carolina Michaëlis de Vasconcelos forgotten sketch of an unfinished monograph on E(n)-zebra "Wild donkey". Boletim de Filologia 30: 1-11.

MASSETI M. 2003. - Estinzione del carnivori e degli ungulati Italiani nell'Olocene, in BOITANI L., LOVARI S. \& VIGNA-TAGLIANTI A. (eds), Fauna d'Italia. Mammalia III Carnivora-Aryiodactyla. Calderini, Bologna:1-16.

MenéNDEZ-PIDAL R. 1906. - Primera crónica general: Estoria de España que mandó componer Alfonso el Sabio. Bailly-Baillière e hijos, Madrid, $776 \mathrm{p}$.

MrtChell D. W. 1859. - Wild Asses. Once a Week, November 26: $454-458$

Morales A. 1994. - Earliest Evidence of Genets (Genetta genetta: Mammalia, Viverridae) in Europe. Nature 370 (6490): 512, 513.

Morales A. \& RofES J. 2008. - Early evidence for the Algerian Hedgehog in Europe. Journal of Zoology 274 (1): 9-12

Morales A., Riquelme J. A. \& Liesau C. 1995. - Dromedaires in Antiquity: Iberia and beyond. Antiquity 69 (263): 368-375. 
NisARD C. 1887. - Venance Fortunat. Poésies mêlées. Librairie de Fermin-Didot et Cie, Paris, 295 p.

NORES C. \& LiesAu C. 1992. — La zoología histórica como complemento de la arqueozoología. El caso del zebro. Archaeofauna 1: 61-71.

NUNES J. J. 1925. - Tentativa de identificaçáo do animal chamado zevro nos documentos medievais. Boletim da Seguda Classe da Academia das Sciencias de Lisboa 16: 427-436.

Orlando L., MashKour M., Burke A. , Douad C. J., EisemanN V. \& HÄNNI C. 2006. - Geographical distribution of an extinct equid (Equus hydruntinus: Mammalia, Equidae) revealed by morphological and genetical analyses of fossils. Molecular Ecology 15: 2083-2093.

Orlando L., Metcalf J. L., Alberdi M. T., Antunes M. T. Bonjean D., Otte M., Martin F., Eisenmann V., MashKour M., Morello F., Prado J. L., Salas-gismondi R. B., Shockey D., Wrinn J., Vasil'ev P. J., Ovodov S. K., Cherry N. D., Hopwood M. I., Male B., Austin J. J., Hänni C. \& CoOper A. 2009. - Revising the recent evolutionary history of equids using ancient DNA. Proceedings of the National Academy of Sciences 106 (51): 21754-21759.

Oroz J. \& Marcos M. A. 1994. - San Isidoro de Sevilla. Etimologías (bilingual Edition) II. (Libros XI-XX). Biblioteca de Autores Cristianos, Madrid, $614 \mathrm{p}$.

OrTega Rubio J. 1918. - Relaciones topográficas de los pueblos de España. Lo más interesante de ello. Sociedad Española de Artes Gráficas, Madrid, $710 \mathrm{p}$.

Pagnier C. J. 1821. - Théorie de l'extérieur du cheval. Chez Madame Muzard, Paris, $428 \mathrm{p}$.

Pallas P. S. 1794. - Voyages du Professeur Pallas, dans plusieurs provinces de l'Empire de Russie et dans l'Asie Septentrionale. Tome septième. Chez Madaran, Paris, 568 p.

Pascual Barea J. 2008. - Razas y empleos de los caballos de Hispania según los textos griegos y latinos de la antigüedad, in SANTAMaría M. T. (ed.), La transmisión de la ciencia desde la Antigüedad al Renacimiento. Ediciones de la Universidad de Castilla-La Mancha, Cuenca: 117-202.

PigafeTtA P. 1591. - Relatione del reame di Congo et delle circonvicine contrade. Tratta dalli scritt and ragionamenti di Odoardo Lopez, portoghese. Con dissegni vari do Geografia, di piante d'abiti, d'animali and altro. Bartolomeo Grassi, Roma, $82 \mathrm{p}$.

PigafeTta F. 1597. - A report of the Kingdom of Congo, a Region of Africa and of the Countries that border round about the same. Drawn out of the writings and discourses of Odoardo Lopez, a Portingall, by Filippo Pigafetta. John Wolfe, London, 220 p. Translated from Italian by Abraham Hartwell.

Real Academia Española: Banco de datos (CORDE) Corpus diacrónico del español. Database resource consulted June 11th, 2008 from http://www.rae.es
RIDGEWAY W. 1905. - The Origin and Influence of the Thoroughbred Horse. Cambridge University Press, Cambridge, 538 p.

Roda L. 2009. - American Sorraia Mustang, in LYNGHAUGH F. (ed.), Horse Breeds Standards Guide - The Complete guide to the Standards of All North American Equine Breed Associations: Endorsed and Verified by North American Equine Registries. Voyager Press, Minneapolis: 32-26.

Rosell C. 1953. - Crónicas de los Reyes de Castilla desde don Alfonso el Sabio hasta los Católicos don Fernando y doña Isabel. Tomo I. Ediciones Atlas, Madrid, 229 p.

SANTA ROSA DE VITERBO J. DE 1799. - Elucidario das palabras, termos e phrazes, que em Portugal antigamente se usaram e que hoje regularmente se ignoram. Tomo II $G$ - $Z$. Typographya Regia Silviana, Lisboa, 416 p.

SANTOS E. \& SANTOS J. 2011. - Disertación sobre el animal Zebra. Nacido, criado, conocido y cazado antiguamente en España, en donde ya no se encuentra por el R. P. Fray Martín Sarmiento. Estudio preliminar. Museo de la Educación, La Laguna, 36 p.

SCIO DE SAN MIGUEL P. 1814. - Biblia vulgata latina traducida en español. Tomo IX del Antiguo testamento, La prophecía de Isaías y la de Jeremías. Imprenta de Ibarra, Madrid, 599 p.

SiLVEIRA J. DA 1948. - Estudos sobre o vocabulário português (Formas, sentidos, prosódia, origens). Zevro. Zebra. Revista Portuguesa de Filólogia 2: 220-247.

TERrón M. 1987. — De la Extremadura agreste: notas para un estudio de la evolución histórica de la fauna de caza mayor, in $\mathrm{La}$ Caza en Extremadura. Diputación de Cáceres, Cáceres: 31-70.

THEVENIN R. 1943. - La faune disparue de France, depuis les origines jusqu'à nos jours. Payot, Paris, $326 \mathrm{p}$.

Uerpmann H. P. 1990. — Die Domestikations des Pferdes im Chalkolithikum West- und Mitteleuropa. Madrider Mitteilungen 31: 109-153.

UREÑA R. DE. 1911. - El fuero de Zorita de los Canes según el códice 217 de la Biblioteca nacional (siglo XIII al XIV) y sus relaciones con el fuero latino de Cuenca y el romanceado de Alcázar. Imprenta Fortanet, Madrid, $423 \mathrm{p}$.

VAldeón J. 1980. — La Peste Negra. La Muerte Negra en la Península. Historia 16 (56): 60-66.

VALDEVIRA G. 1996. — La provincia de Albacete durante el reinado de Felipe II, según las "Relaciones topográficas". Al-Basit 23 (39): 157-215.

WilLMS C. 1989. — Zum Aussterben des europäischen Wildesels. Germania 67: 143-148.

Wolf F. J. \& Hofmann C. 1856. - Primavera y flor de romances, ó colección de los más viejos y más populares romances castellanos. Tomo segundo. A. Asher and Socii, Berlin, $452 \mathrm{p}$.

Zeder M. 2012. - Pathways to animal domestication, in BetTinger R. L., Gepts, P. \& FAmula, T. R. (eds), Biodiversity in Agriculture: Domestication, Evolution, and Sustainability. Cambridge University Press, Cambridge: 227-259. 